\title{
ETHICS AND BASIC PRINCIPLES OF RESTORING HISTORICAL STONE MONUMENTS
}

\section{ŁUKASZEWICZ Jadwiga W. ${ }^{1}$}

${ }^{1}$ Professor of stone conservation in the Institute of Archeology in Nicolaus Copernicus University; jwluk@umk.pl https://orcid.org/0000-0003-0049-8171

ABSTRACT: The paper discusses ethical guidelines in relation to the conservation of historical monuments made of stone. The presented rules consider the building stone specificity and its susceptibility to various corrosion factors and the character of deteriorated areas in that kind of historic monuments. The basic conservation rule sounding Primum non nocere is deconvoluted to more particular principles like: (i) to preserve authentic historical matter as a carrier of artistic, scientific and historical value of the object, (ii) to provide minimal scale of intervention, (iii) to provide the reversibility of the methods and particularly materials used from conservation or reconstruction works, (iv) to provide distinguishability of reconstructions parts and (v) to provide the integrity of the work of art. The adaptability of these particular rules to the of conservation of stone artistic artefacts is also presented.

KEYWORDS: Stone conservation, ethics and principles of restoration

"To save the national legacy from oblivion and pass it down to posterity has always been a holy and dear obligation of all peoples." Monumenta Regnum Poloniae Cracoviensia from 1821.

For centuries „rock” or „stone" have been considered as materials of exceptional durability and resistance which is proved by proverbs or records in literature of many nations, religions or cultures. However, also these materials deteriorate in the course of time. The pace and mechanism of corrosion depend on the mineral constitution of the rock and the conditions to which they have been exposed to. Rocks have been a subject of the creative activity of sculptors and stonemasons, who have created magnificent sculptures or architectural details. These works of art have often been displayed outside, in changeable climates, exposed to rainfall as well as solid and gaseous air pollution. This results in damage which can be divided into two basic groups: this which is impossible to identify on visual inspection i.e. cracking inside the element or stone disintegration under covering layers, and the one which can be identified visually e.g. black crusts formed on the stone surface, cracking, peeling off, 
detached fragments, granular disintegration (Fig. 1 and 2). Particularly in the latter case, when the damage is clearly visible, the historical objects become subject to conservator-restorers' work.

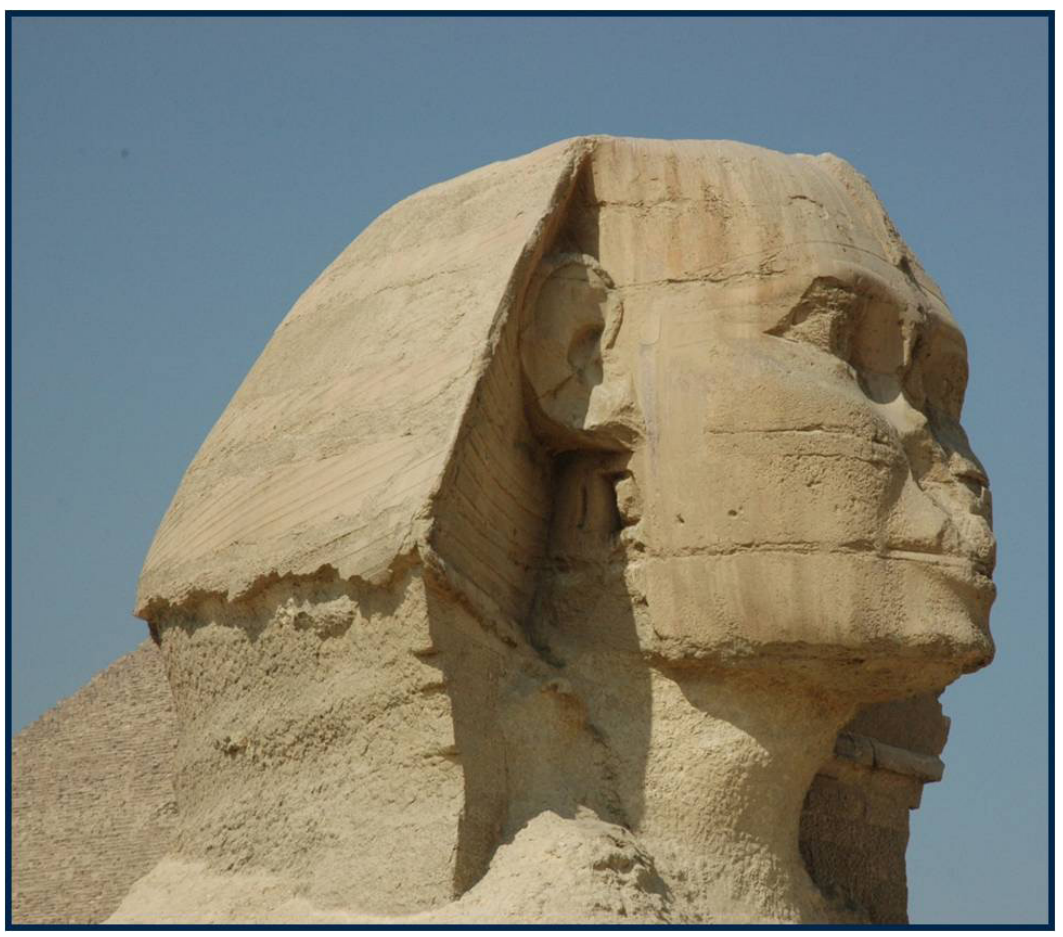

Fig. 1 Egypt, Sphinx, deterioration of lime stone (J. W. Łukaszewicz)

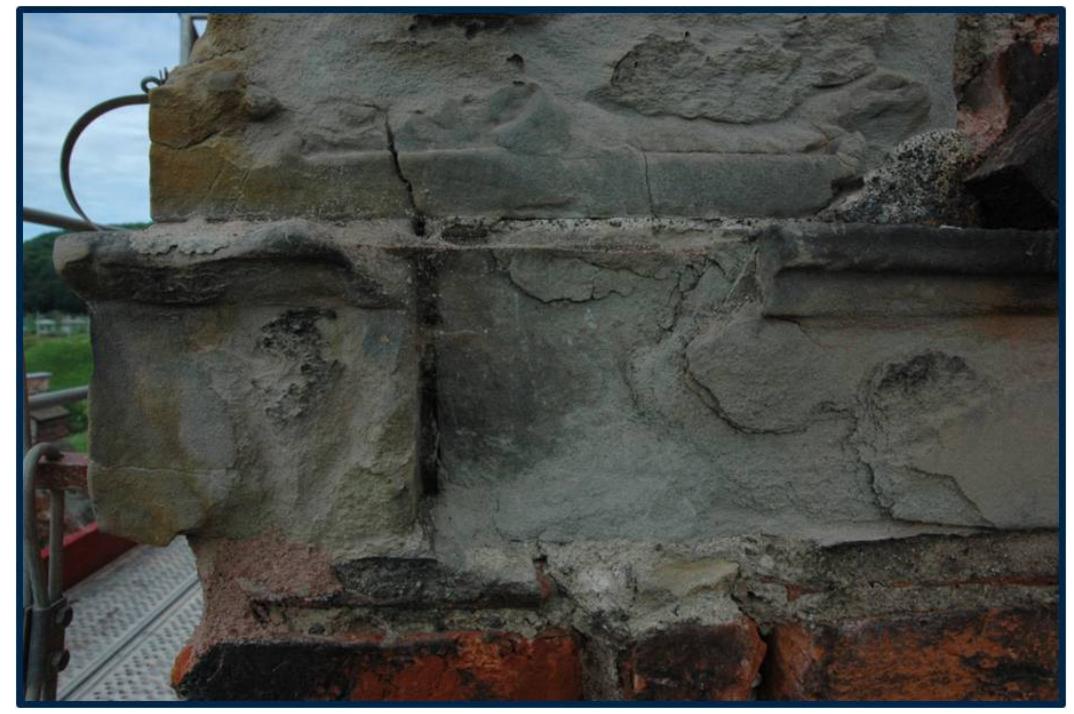

Fig. 2 Gdańsk, sandstone Gotland, architectonic detail - black crusts formed on the stone surface, cracking, peeling off, detached fragments, granular disintegration (J. W. Łukaszewicz) 
Let us ask a question: What are the rules of restorer's intervention? Are they constant regardless of the type of object, or just the opposite? What is the acceptable extent of restorers' intervention?

The conservator-restorers' protection covers historical monuments and works of art. According to the definition used in the "Polish Law on protection and conservation of historical monuments", a historical monument is „, a piece of real estate (immovable property) or a movable property, their parts or groups, which have been created by man or as a result of human activity and which constitute a testimony of the bygone epoch or event, whose preservation is of social interest due to its inherent historical, artistic or scientific value" (Law of 23.02.2003, Art. 3, item 1). As regards a piece of art, it was perfectly defined by Professor Wojciech Krupnik from the Academy of Fine Arts in Warsaw who, referring to the discourse of the ancient philosophers - Plato and Aristotle, said that it is ,a place where an idea and matter met and were transformed into beauty" (Kurpik, 2007, pp. 29-30).

Thus, a restorer's task is to preserve both the original (authentic) material and form of a piece of art, as well as its function and the place where it is displayed, which is a crucial issue in the case of tombstones. In the context of restoration of historical monuments, a particular emphasis must be put on the protection of their artistic, historical and scientific values.

An idealistic aim of the activities connected with conservation of cultural heritage and historical monuments is taking special care to preserve the monuments and artefacts in their original form for posterity. Achieving this aim requires preserving the authentic matter which is the carrier of form, that is, the creator's idea. As regards historical stone monuments, it is a particularly challenging and debatable issue as the damage can be frequently very extensive and the necessary restorer's intervention both in the material and non-material sphere can be likewise deep and extensive.

The scientific principles of stone monument restoration were created parallelly to the heated debate held between the supporters of Eugene Emanuel Viollet-le- Duc (1814-1879) and those of John Ruskin (1819-1900). Although Eugene E. Viollet-le-Duc did not create strict rules of restoration procedure, he accepted a far-reaching transformation in order to return an object to its stylistic purity, but also advised an individual approach to each artefact, which has become one of the principal contemporary rules of all restoration activities (Jakimowicz, 1966). John Ruskin, who held a totally opposing view, believed that restoring a historical monument is , a lie, from the beginning to the end" and leads to the destruction of the monument (Frycz, 1975). Therefore, he advocated only preservation works aimed at maintaining the monument in its current state. The discussions created a framework of conservation and restoration procedures. As a result, the first acts were created, such as the Athens Charter and Venice Charter which clearly define and differentiate the scope of conservation and restoration works (Vademecum, 2015).

Historical stone monuments and works of art are an integral part of cultural heritage, therefore the issues concerning the ethics and rules of conduct must not be considered separately. They are closely related to the stone material.

At the turn of the $19^{\text {th }}$ and $20^{\text {th }}$ century the theoretical restoration thought evolved very quickly. Simultaneously, there was intensive research aimed at explaining the mechanisms of deterioration of stone monuments and methods of their conservation. As early as the $19^{\text {th }}$ century, methods of stone consolidation were developed (Annon, 1861; Church, 1862; Barff, 1860; Kessler, 1883). The research on 
the mechanisms of deterioration of stone monuments and developing methods of their conservation is conducted by members of the International Scientific Committee on Stone (ISCS ICOMOS) (www. iscs.icomos.org). Despite the fact that the Committee on Stone does not carry out research on the theory of conservation, all our actions must be in compliance with the theoretical principles, ethics of conservation and rules of conservation conduct.

One of the primary ethical rules in historical monuments' conservation, identical to the one which applies in medicine, is the Hippocrates's „Primum non nocere” - first, do no harm (Gaczoł, 2015). Just as every patient is an individual case for a doctor, every historical monument or work of art is exceptional and treated individually. Therefore, before commencing conservation works, it is of utmost importance to correctly recognize and inspect the monument or work of art. Stone objects are studied using state-of the-art equipment, which allows to put a correct diagnosis as to the cause of the damage or deterioration. Then, a plan of conservation works is prepared in order to select appropriate methods and materials. A decision is also taken as to the extent of the restoration fillings and possible reconstructions. The choice of the materials and conservation methods applied in the conservation works is made on the basis of the simultaneously conducted basic research which aims to invent and develop new methods of performing particular stages of conservation works such as removing crusts, desalination, reinforcement, filling gaps or using hydrophobic agents (water repellents). The main criterion of approving new materials for practical usage is the absence of any impact on or interaction with the historical material i.e lack of any adverse effects that would deteriorate the condition of the stone object. Such approach is in compliance with the principle of "Primum non nocere", which in the case of historical stone monuments is crucial due to their complex mineral composition and porous structure as well as the usually large size of the objects.

A primary rule of conservation is taking care to preserve authentic historical matter as a carrier of artistic, scientific and historical values of the object. In the past, it was a common practice to remove damaged fragments of stone monuments, gaps were enlarged and frequently formed in geometrical shapes in order to facilitate matching fillings made of new stone (Fig. 3) A similar practice was applied in conservation or restoration of brick walls - damaged bricks and mortar were removed and replaced with new ones (Fig. 4). This procedure led to a systematic replacement of authentic elements with new ones. 


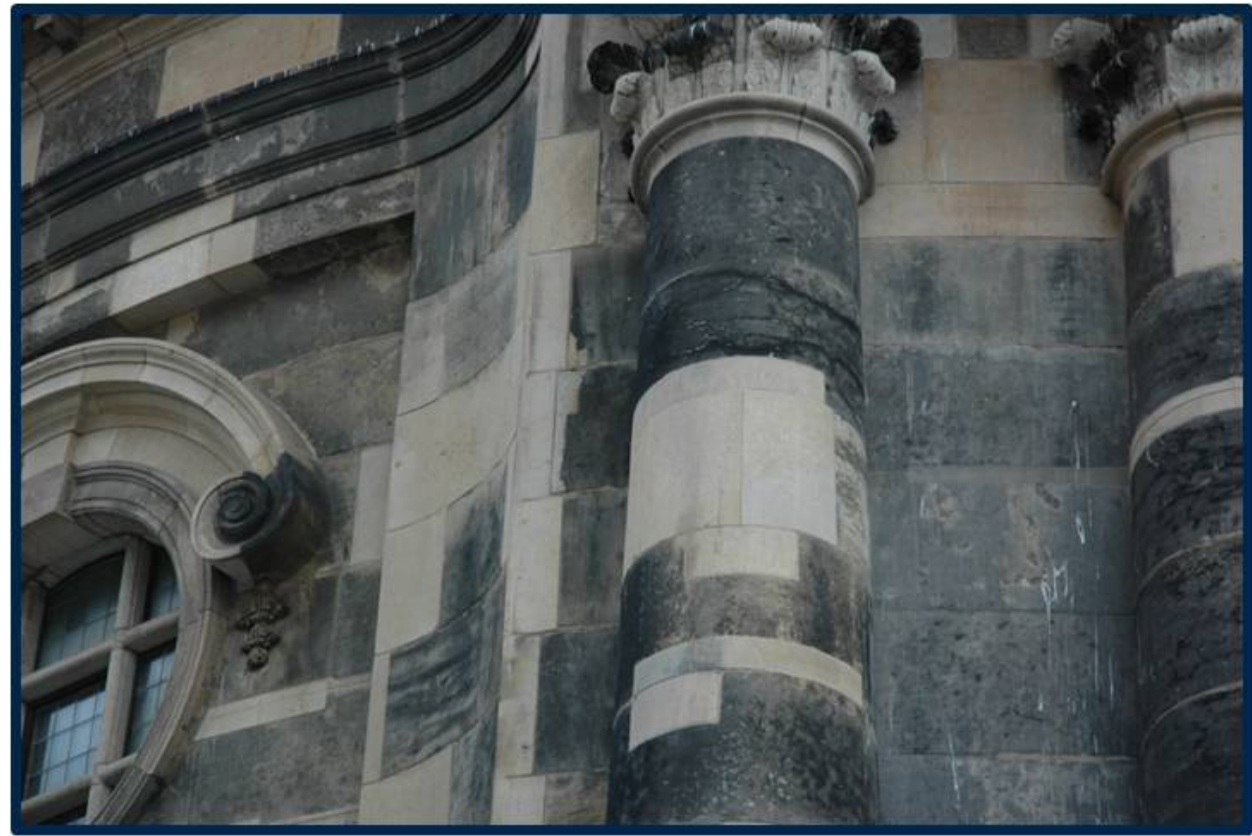

Fig. 3 Dresden, St. Maria Church (Frauenkirche), the gaps were enlarged by the new stone in the geometrical shape (J. W. Łukaszewicz)

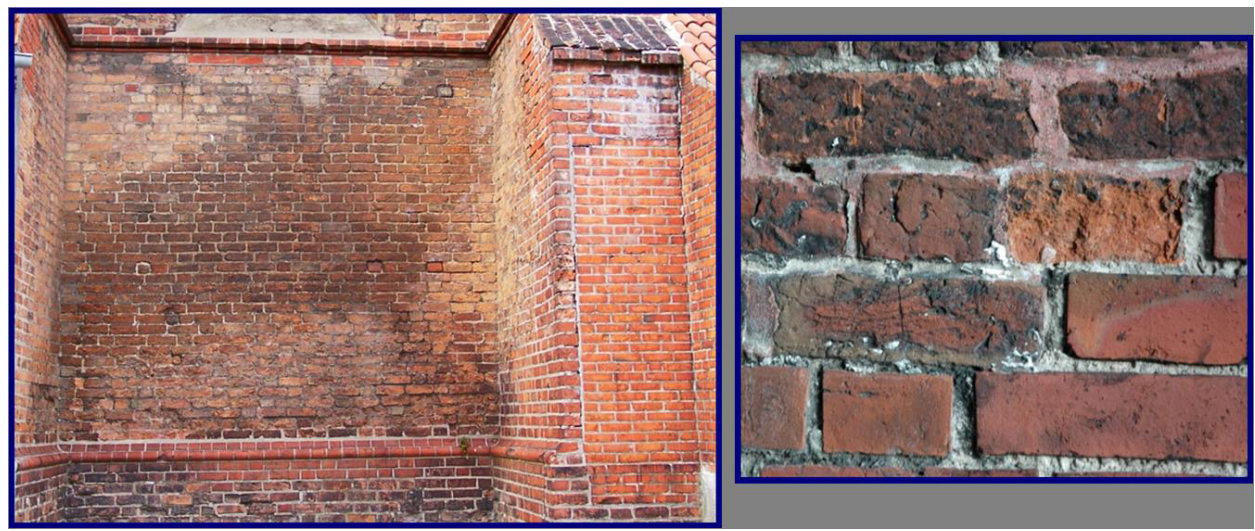

Fig. 4 Brick wall - deteriorated bricks were replaced by the new ones, Chelmno St. Mary Church (J. W. Łukaszewicz)

The development of new technologies has provided new materials, recently even in nano-scale, and gave us at our disposal numerous substances and methods which enable an effective consolidation of disintegrated and weakened stone elements. It allows to preserve the original material to a full extent (Łukaszewicz, 2002). While studying an object prior to commencement of conservation works, one must pay a particular attention to the historical transformations which have been made to the historical monuments for example secondary layers of paint or added architectural details.

Their preservation testifies to the history of the object and has an exceptional historical and scientific 
value. However, each case should be considered on an individual basis, as it was a frequent practice, particularly in the 19th century, to use materials which had a detrimental effect on stone monuments. In such cases, it is necessary to entirely or partly remove such additions. Thus, we are moving on to the next rule of conservation procedure - the so-called minimal intervention. When is it applied? Basically, it concerns all stages of stone monuments conservation. However, we often face this problem when removing secondary additions.

The scope of works in such case must be limited only to the removal of only the secondary additions which, due to their structure and properties, adversely affect the condition of the existing original stone and may contribute to faster deterioration of the original matter. These include cracked oil paint layers which peel off together with the underlying base which seal the stone and prevent unobstructed evaporation of water from the object, or mortars, plasters or cement screeds. The principle of minimum intervention also refers to the process of consolidation of historical monuments.

The preferred materials are those which effectively reinforce the stone, are evenly distributed throughout the object, for example TEOS (consolidants base on tetraethoxysilane), but the amount of the substance introduced into pores is scarce so that it forms thin layers inside the pores. Consequently, the open porosity of the stone is not reduced more than by $20 \%$ (Eukaszewicz, 2002). It is also debatable to use water repellents as they cause a permanent and irreversible change of the hydrophilic properties of stone into hydrophobic ones.

A separate issue is the extent of reconstruction. It also requires individual approach. There are objects of exceptional artistic and historical value, with a certain image created in the past, e.g. the Venus of Milo or the Nike of Samothrace, for which nobody will make decision to carry out partial reconstructions. It is much easier to make such decisions in the case of sculptures which are known to local communities or are cult objects. They are frequently reconstructed, maybe completely or only partially, however not always on the basis of a properly prepared archival documentation (Warsaw Recommendation 2018).

Another frequently mentioned rule of conservation is the reversibility of the methods and particularly materials used from conservation or reconstruction works, i.e. making sure that all the materials introduced into the historical object can be removed without damaging the original material and new, superior substances can be then introduced. Unfortunately, during conservation of stone monuments, this rule cannot be fully observed, especially with regard to materials used in order to reinforce disintegrated material or to make it hydrophobic. Although the substance introduced into the pores of the material may be permanently soluble or reversible itself, its removal from the object may be very difficult or just impossible. Other procedures such as filling gaps or reconstructions are reversible. Removing mortar or plaster is possible provided that they have been correctly selected for matching the properties of the particular stone type. If their durability and adhesion to the original stone is too great, there may be a problem with reversing such procedure and it may result in damaging the original. This refers to chemo-setting adhesives, which are commonly used for gluing stone. They are also hard to remove due to the lack of possibility to dissolve them after they set. 
A subject of numerous discussions on the theory of conservation of cultural heritage, particularly in the case of mural paintings, has been the issue of distinguishability of fillings and reconstructions and their extent. One must mention Cesare Brandis theory here (ed. Szmelter \& Jadzińska, 2007). In the case of stone monuments, the theory is implemented in various ways. In the past, the scope of reconstruction was frequently limited only to the reconstruction of repeated elements or recognizable architectural details. It was often made using natural stone or mortars which were clearly noticeable. Currently, the scope of reconstruction is much wider, but it must be always based on iconographic documentation allowing to perform the task correctly.

As far as fillings and reconstructions are concerned, the only distinguishing feature can be a slight difference in colour. As regards the texture of the materials used for reconstruction, it is based on the choice of the components and the properties of the mortars and the natural stone. Their physical properties are a basic criterion of their choice, that is, they must be analogous or compatible with the original. In this way, we have reached one of the last important principles of conservation works i.e. the integrity of the work of art, or its final arrangement, and consequently its aesthetic reception. This issue is not only important from the point of view of the specialists in conservation-restoration but also for social and environmental reasons. We should aim at maintaining cohesion and integrity of the entire object instead of creating "conservation compositions" which are obscure and incomprehensible for the recipients of the work of art.

A good example of such a conservation procedure is the epitaph of Andreas Gretsch and his wife Anna in the SS Johns' cathedral in Torun. The masterpiece has been preserved since 1527 and although it has been housed inside the church it was nevertheless exposed to various adverse factors such as fire, leaking roof, or being covered with a thick layer of oil paint (Fig. 5). During the conservationrestoration works, the thick layers of paint were removed, thus revealing the beauty of the central presentation with sculpted details, gilding and polychromy. The architecture of the epitaph was reconstructed with mortar, which composition was similar to the original ones - with the Gypsum binder (Estrichgips).

However, due to the lack of iconographic sources which were the basis for the sculpture in alabaster which constitutes the central scene of the epitaph, that is "The Descent of Christ from the Cross", the reconstruction of this scene has not been undertaken. The background of the central scene, a painting on a wooden board, was subject to a special treatment. After removing the layer of white paint, the painting was reintegrated with a tonal adjustment, leaving two chronologically different layers of paint, as the wooden boards were probably used secondarily (Fig. 6). 

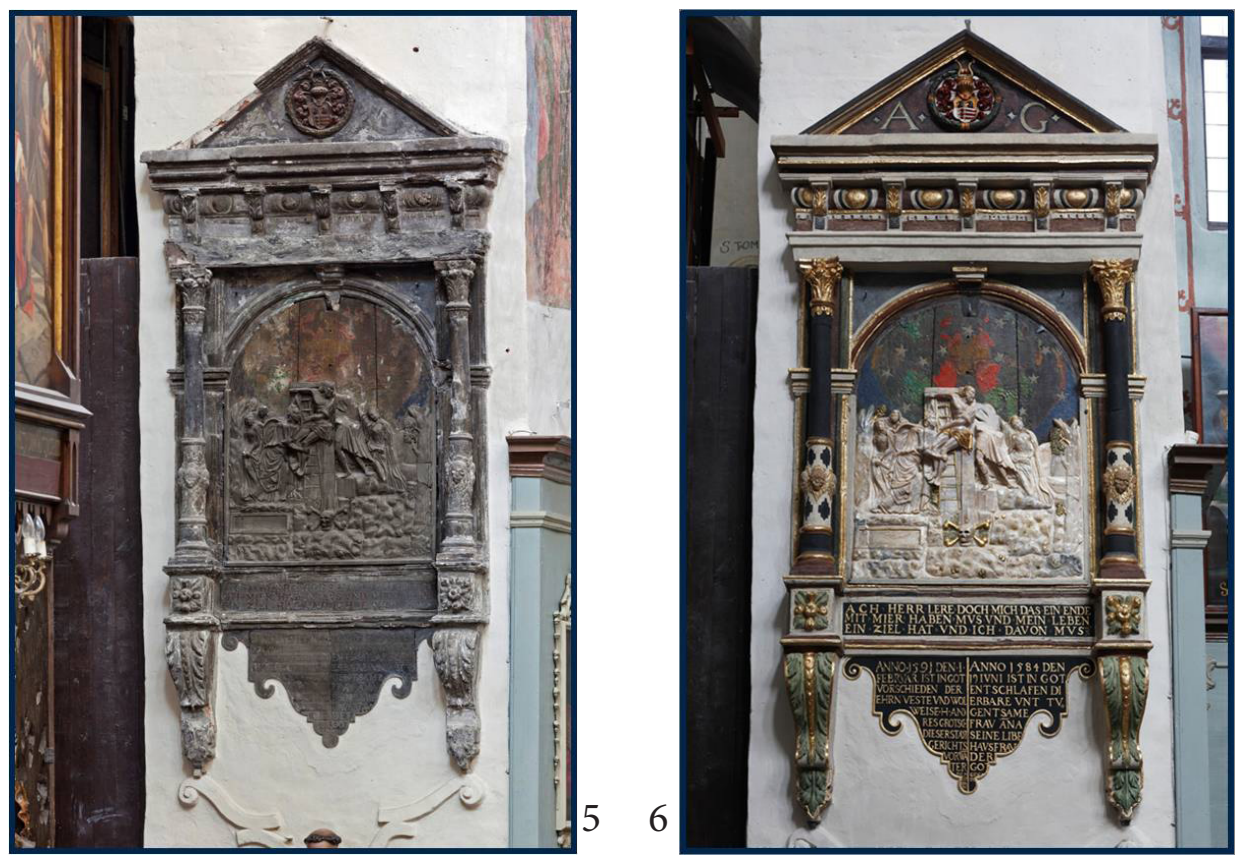

Fig. 5 Torun, the SS Johns' cathedral, the epitaph of Andreas Gretsch and his wife Anna, before conservation - 2015 (A. Skowroński)

Fig. 6 Torun, the SS Johns' cathedral, the epitaph of Andreas Gretsch and his wife Anna, after conservation - 2016(A. Skowroński)

\section{Conclusions}

Taking into account the fact that historical stone monuments are a part of our cultural heritage, they must not be subject to separate, different ethical principles or rules of conduct.

- The ethics of conservator-restorer's profession is of utmost importance, and apart from the principle of „Primum non nocere” it must be supported by a thorough knowledge and skills of the highest standard.

- Despite the permanence of the principles governing the preservation of cultural heritage, they require certain modifications depending on the various typologies of historical monuments and therefore a particularly important issue is the individual approach to each object.

- Certain distinctness in implementing the basic principles of conservation-restoration works on historical stone monuments results from the composition and properties of the stone materials.

In conclusion, it must be emphasized that apart from the compliance with the principles of conservation-restoration procedure, it is an obligation of the persons involved in the protection of cultural heritage to conduct interdisciplinary studies of works of art, which was already emphasized by Cesare Brandi with the creation of the Istituto centrale per il Restauro in Rome. 


\section{Bibliography}

Anon (1861), Stone preserving processes, The Builder 19

The Art of Conservation and Restoration, Cesare Brandi (1906-1988) His Thought and the Heritage Debate. Art of Conservation-Restoration in Poland, ed. Szmelter I. \& Jadzińska M., Warsaw 2007

Barff F. S. (1860), Stone Artificial, Stone Preserving: Stone Colouring, British Patent 2608, Oct. 26, 1860

Church A. H.(1862), Stone Preserving and Colouring, Cements, British Patent 220, Jan. 28, 1862

Frycz J. (1975), Restauracja i konserwacja zabytków architektury w Polsce w latach 1795-1918, PWN Warszawa 1975

Gaczoł A. (2015), Pomiędzy zasadą Primum non nocere a idea integracji dziedzictwa „przeszłość w przyszłości" Pierro Gazzoli. Polityka kształtowania zasad niezbędnej ingerencji konserwatorskiej/ Between the primum non nocere principle and the concept of heritage intergation 'The past in the Piero Gazzola policy of establishing the principles of necessary conservatio Wiadomości Konserwatorskie / Journal of Heritage Conservation (43), 2015 pp.

Jakimowicz T. (1966), Viollet le Duc, architekt-konserwator i jego zwiąki z Polską, Ochrona Zabytków, 19/3 (74), pp. 3-12

Kessler L. (1883), Sur un procédé durcissement des pierres calcaires tendress an moyen des fluosilicates á base d’oxydes insoluble, Compte Rendu, Académie des Science, Intitute de France, 96, pp. 1317-1319 Kurpik W. (2007), Co w istocie konserwujemy? (What do we actually restore?), [in:] The Art of Conservation and Restoration, Cesare Brandi (1906-1988) His thought and debate on heritage. The art of conservation-restoration in Poland edited by I. Szmelter i M. Jadzińska, Warsaw 2007, pp. 2930, ISBN: 978-83-60192-46-7, 978-83-922954-3-3

LAW of 23 July 2003 on Protection and conservation of historical monuments, Art.3, item 1, http:// prawo.sejm.gov.pl/isap.nsf/download.xsp/WDU20031621568/U/D20031568Lj.pdf

Łukaszewicz, J. W. Badania i zastosowanie zwiazków krzemoorganicznych w konserwacji zabytków, UMK Toruń 2002. IsBN: 83-231-1445-5

Warsaw Recommendation on Recovery and Reconstruction of Cultural Heritage, ed. Magdalena Marcinkowska, Dabrówka Lipska, Warsaw 2018, ISBN: 978-83-66160-14-9

Vademecum Konserwatora Zabytków, Międzynarodowe Normy Ochrony Dziedzictwa Kultury /edycja 2015/, PKN ICOMOS, Warszawa 2015, ISBN: 978-83-940280-4-6 
